\title{
How Does Adaptive Governance Help Restore and Protect Shared Waters?
}

\author{
Gail Krantzberg1* ${ }^{*}$ Zilin Song ${ }^{2}$ \\ ${ }^{1}$ McMaster University, Hamilton, Ontario, Canada \\ ${ }^{2}$ Northeast Normal University, Changchun, China \\ Email: ^krantz@mcmaster.ca, songzl781@nenu.edu.cn
}

How to cite this paper: Krantzberg, G. and Song, Z. (2020) How Does Adaptive Governance Help Restore and Protect Shared Waters?. Open Access Library Journal, 7: e6833.

https://doi.org/10.4236/oalib.1106833

Received: September 17, 2020

Accepted: October 26, 2020

Published: October 29, 2020

Copyright $\odot 2020$ by author(s) and Open Access Library Inc.

This work is licensed under the Creative Commons Attribution International License (CC BY 4.0).

http://creativecommons.org/licenses/by/4.0/

(c) (i) Open Access

\begin{abstract}
When watersheds span multiple administrative jurisdictions, ensuring the equitable division of responsibility, conflict resolutions and information sharing are all needed to achieve ecological balance, economic development, and social security. Under socio-ecological conditions full of uncertainties, diverse participating groups and multiple perspectives on resource threats need to be involved. Adaptive governance as a theory refers to the structures and processes by which people can address successive interventions and optimize governmental decisions. Through reviewing existing research and analyzing case studies, we uncover problems for shared water governance and highlight attributes of good adaptive governance processes. We emphasize the importance of learning, resilience, as well as accountability, and discuss how these features have the potential for building effective governance with adaptive capacity. We propose a conceptual model to help enable and measure the adaptive capacity for shared water governance at regional scale.
\end{abstract}

\section{Subject Areas}

Hydrology

\section{Keywords}

Adaptive Governance, Shared Waters, Effectiveness Assessment

\section{Introduction}

Water governance is the range of political, organizational, and administrative processes (Nowlan and Bakker, 2010) [1]. Three core concepts were included here, i.e. processes, institutions, and multiple actors (Lautze et al., 2011) [2]. For shared waters, watersheds overlap political and administrative boundaries and 
pose a challenging frame of reference for citizens (Ferreyra and Kreutzwiser, 2008 [3]; Fish et al., 2010 [4]). Not only should we consider how to achieve and maintain ecological balance, economic development and societal well being, but also to respect the needs for meaningful participation of divergent states, institutions, and citizens. The broader the participating groups involved, the more diverse perspectives and talents of the collaborative in addressing ecosystem protections, managing risks, and valuing water (Giordano and Wolf, 2003) [5].

Governance, taken as the process of informing, making, implementing and refining decision on specific issues and policies (Davis, 2014) [6], is complicated since uncertainties are inevitable, particularly when it raising the challenge of who should be engaged who should engage and how that engagement would be most meaningful. Dietz et al. (2003) [7] also pointed out that making tough decisions under uncertainty, complexity, substantial biophysical constraints and conflicting human interests are a challenge when devising ways to sustain earth's ability to support human and nonhuman resilience.

The number of studies in terms of adaptive governance has increased since 2005 (Karpouzoglou et al., 2016) [8]. Emphasized in the literature is the need to adapt governance frameworks to navigate complex social-ecological systems through periods of gradual and episodic changes in order to ensure sustainability (Akamani and Wilson, 2011; Brugnach et al., 2008) [9] [10], and improve the adaptive capacity of the most vulnerable (Hurlbert and Diaz, 2013) [11].

In applying adaptive governance to the research field of shared waters, we developed a conceptual model that helps meet the specific needs of shared water governance at regional scale and a criteria system for the assessment of adaptive properties. We assumed the governance process with adaptive capacity operates as a feedback loop, namely "formulation-feedback-learning-adjustment". With case studies, problems in the existing governmental institutions were revealed and some intentional governmental efforts to foster adaptive governance were suggested.

\section{Attributes of Adaptive Governance Processes}

The social features and processes of decision making is required after facing environmental disturbances (Folke et al., 2005) [12]. Governance characterized by excellence, in detail, should be conducive to the long-term advancement and protection of nature, society and economy, such as pollution cleanup, job-creation, and provision of social support systems.

Adaptive governance as a theory further brings attention to actors' involvement in cross-scale interactions, collaborative arrangements with self-organizing capabilities (Huitema et al., 2009) [13]. Most literature emphasizes experimentation, learning, and participation as attributes of governance that are actively planned for in decision making (Munaretto et al., 2014) [14]. Thus, governance principles with greater adaptive capacity are expected to be more effective in addressing uncertainties address uncertainties. This topic is likely to continue to attract academic, policy and public interest (Karpouzoglou et al., 2016) [8]. 
The process of policy formulation, followed by implementation and monitoring enables the participants to continually optimize their interactions. The ideal state of adaptive governance is to establish a nimble plan through a series of comprehensive strategies, which can be revised when necessary and can be adapted to various conditions. Three key features were adopted here, namely learning, resilience, and accountability.

Pahl-Wostl (2009) [15] noted that social and societal learning proceeds in a stepwise fashion moving from single to double to triple-loop learning. Learning helps develop adaptive expertise (an individual's ability to deal flexibly with new situations) and the processes of sense-making (Weick, 1995) [16]. The whole process of learning can be summarized as the practice of continual planning, implementation and monitoring, gaining experience and optimizing results. Several steps are required to make this happen including identifying the participants, sharing information, knowing who benefits and who is at risk, as well as thorough communications to set common goals. Informal networks are considered to play a crucial role in such learning processes (Pahl-Wostl, 2009) [15].

Regard the governance process as a system, resilience refers to the capacity of adapting to and shaping change (Berkes, 2008) [17]. It determines the relationships within the systems and measures their ability to absorb changes of state variables, driving variables, parameters, to be resilient (Holling, 1973) [18]. Walker et al. (2004) [19] stated that in a social-ecological system with high adaptability, the actors can reorganize the system in response to the disturbance events. Resilience, as a concept, links learning and adaptability, and requires inclusive organizations and sustainable supporting systems to build the capacity to respond to uncertainties and risks (Djalante et al., 2011) [20].

Accountability refers to whether and how the allocation and acceptance of responsibility for decisions and actions were met (Lockwood et al., 2010) [21]. Accountable authorities who pursue just distributions of benefits and involuntary risks can enhance the adaptive capacity of vulnerable groups and society as a whole (Lebel et al., 2006) [22]. Different mechanisms of accountability could create channels of interaction and a basis for trust between government and citizens (Ribot, 2002) [23]. Increasing transparency with better information flows to enhance governance practices is a good example (Badenoch, 2002) [24].

\section{Problems of Existing Governance Approaches for Shared Waters}

Water governance issues were "born" neither as scientific problems nor as multi-criteria problems (Salgado et al., 2009) [25]. Advancing knowledge of how adaptive governance can contribute to the excellence of shared waters requires grounding abstract theories with applied experiences. Therefore we consider several case studies on shared water governance that demonstrate the attributes of different governance approaches.

Collingwood Harbour

Situated on the south shore of Nottawasaga Bay, which constitutes the south- 
ern extension of Lake Huron's Georgian Bay (Krantzberg and Houghton, 1996) [26], Collingwood Harbour was an important industrial wharf in the past and included a Canadian Steamship Limited vessel construction installation The ecosystem injuries, such as eutrophication, degradation of habitats, disappearance of wetlands, hardening of coastlines and contaminated sediment affected the area long after the shipyard was closed, limiting the long-term development of the area. In the process of governance, a Remedial Action Plan (RAP) assembled by the federal and provincial governments (GLWQA 2012) made an important contribution to the successful transition of harbour development. It has improved the governance of the harbour through inclusiveness, learning and accountability (Krantzberg, 2012) [27].

As Mostert (2015) [28] states "how the environment is managed depends on who manages it". In this case, the institutional framework embodies the principle of "empowerment", which guarantees multi-participation, protection of multiple interests and assignment of responsibility. In the governance process for Collingwood Harbour, stakeholder participation was ensured when members of the public became involved in RAP decision-making through a public advisory committee (Beierle and Konisky, 2001) [29]. The governance process respected public values and local experiences, resolved conflicts, and established government-stakeholder connections to increase trust and decision-making capabilities of all parties.

Another factor in the success of the RAP was the governance capacity for learning. In 1988, facing environmental changes, participants began to focus on raising public awareness of the environment. Through the process of arriving at consensus, the leaders, staff, volunteers, partners and other organizational structures were engaged in activities including school education, transportation planning, trail management, social innovation, for example. As a result of efforts to enhancing community's decision-making capacity, an optimized network was established (Krantzberg, 2006) [30].

The governance process in Collingwood Harbour included different social roles for residents, government, business, educators, farmers, engineers, scientists, conservation authorities, town staff, and journalists. Democratic participation resulted in generating a common understanding of causes of impairments, the options for their resolution, and the sharing of public responsibilities. Overall, governance for the Collingwood Harbour RAP was a process in which government decision making was transitioned to collaborative decision making that addressed the needs of various sectors and town leaders and enabled local decision making with the technical and policy support by governments (Krantzberg and Farrer, 2019) [31].

\section{The Baltic Sea}

The Baltic Sea is an inland sea in northern Europe, with nine countries along the coast: Sweden, Finland, Russia, Estonia, Latvia, Lithuania, Poland, northeastern Germany, and eastern Denmark. It is especially sensitive because of biophysical features such as low salinity and limited rates of replenishment (Hassler 
et al., 2013) [32]. This sensitivity, in combination with high population density and considerable economic activity in this region, makes Baltic Sea ecosystems vulnerable (Andersen et al., 2010) [33]. Additionally, the economic development level of coastal countries is highly varied so that it is difficult to carry out joint governance through negotiation or communication. Fortunately countries along the Baltic Sea have a common vision for marine governance, which is to sustainably use the highly valued natural resource for long-term goals. Therefore, although the Baltic States have experienced dramatic changes in their political scene in recent history and are now still rebuilding their administrative, economic and other capacities (Kapaciauskaite, 2011) [34], coastal countries continually adapt to changes in the political landscape, actively carry out international cooperation, and make important breakthroughs in the governance process, such as the Helsinki Convention and the Helsinki Committee.

Some challenges still exist. For example, the governance regime of the Baltic Sea is diverse, and the participants are mostly from international organizations and elite groups, including authorities, scientific experts and politicians. In contrast, public voices are rare. As Arntein stated that "ladder of citizen participation" distinguishes different formats of participation according to the degree of public empowerment. The situation where stakeholders are granted power in the decision-making process is very different from simply taking their views into consideration (Arnstein, 2019) [35]. For example, due to the limitations of scientific knowledge of the natural environment, eutrophication becomes the environmental risk that receives the most media attention and is also considered to be the biggest threat (Jönsson, 2011) [36]. Since the Baltic Sea is a semi-enclosed saltwater sea with a unique ecosystem, genetic diversity is very important but receives little attention. For this reason, governance might be advanced if more diverse experts participate in the decision-making process rather than just provide suggestions and theoretical support.

Chesapeake Bay

The Chesapeake Bay is the largest estuary in the United States, surrounded by six states and the District of Columbia. Approximately 16 million people live in the Chesapeake basin, with the largest concentrations at the tidal headwaters of estuarine tributaries around the Washington DC, Baltimore, Richmond, and Norfolk metropolitan areas (Boesch, 2006) [37]. The disposal of treated wastewater, runoff from industry and agriculture, and atmospheric pollution have diminished the quality of the bay's water (Gerlak and Heikkila, 2006) [38]. Due to the complicated economic needs, water governance in this area depends on the cooperation of the state governments. By strengthening the accountability system and collaborative mechanisms, the leadership of the United States Environmental Protection Agency has been accepted, and an independent evaluation organization (Implementation Committee) has been established.

Although the state governments are relatively independent, the federal government can still direct the state governments to actively implement work plans through financial support and law enforcement. As such, state governments 
around the Chesapeake Bay need to regularly report whether the progress of restoration is in line with the original target, and quantify and control pollution emissions. In this case, the goal of promoting cooperation and ensuring the effectiveness of river basin governance is relatively strong.

\section{The Mekong River}

The Mekong River is the most important transnational water system in Asia and shared by six countries: Thailand, Cambodia, Laos, Vietnam, Myanmar, and China. Most areas of water governance reform in the Mekong River are highly contested, bringing competing interests and value systems into collision (Hirsch, 2006) [39]. In terms of resource development, Laos and Thailand have a strong demand for electricity and actively promote hydropower development in the tributaries of the Mekong River, while Cambodia and Vietnam have reservations about hydropower development of the Mekong River because they rely on the Mekong River for agricultural and fishery production. In terms of social security, because the Mekong River Basin is located in the Asian monsoon climate zone, coastal countries often face serious risks of drought and flood disasters. Under the situation of global warming and extreme climate events, all countries in the basin need to effectively deal with common problems such as water resource protection, flood and drought disaster management.

In response to the tensions, on January 10, 2018, a five-year action plan for Lancang-Mekong River Cooperation (2018-2022) was published. As a guiding document for the cooperative governance of the Mekong River, it established a framework based on political security, economic sustainable development, and social and cultural development. Specific measures were developed to promote practical cooperation among six countries, including water resource management, ecological and environmental protection, risk assessment, poverty reduction, disaster prevention, disease prevention, tourism, and capacity-building. The initiative improved cooperation among countries and the effectiveness of river governance was enhanced.

\section{Lake Victoria}

Lake Victoria is the largest lake in Africa and is shared by three countries: Kenya, Uganda and Tanzania. The main sources of pollution include the discharge of domestic wastewater, industrial waste, as well as agricultural runoff. Poor governance and low levels of public awareness are accelerating the pollution (Wang et al., 2012) [40]. Lake Victoria also shows us how adaptive governance can potentially benefit tribes.

The fisheries are a good example. There are numerous sources of uncertainty, including the interplay between factors influencing the stock decline of the Nile perch fisheries, such as ecosystem influences, overfishing, illegal fishing, and the potential impacts of climate change (Nunan, 2010) [41]. For the Lake Victoria fisheries, it appears that geographical mobility is the most common response to low catches within an area since developing diversified livelihoods are limited, particularly for those without access to affordable credit (Nunan, 2010) [41]. Each country along the river needs the natural resource to offer food and sup- 
port their economy, but a lack of investment and applicable wastewater treatment technologies have resulted in most of the industrial effluent discharging into the Lake without sufficient treatment (Wang et al., 2012) [40].

The security of funding sources is uncertain, the management process is not transparent, and the accountability in the management process needs to be strengthened. All the above calls for improvement in the governance methods for Lake Victoria. For example, Tanzania and Kenya stipulate a specific fishing technology, but Uganda prescribes the opposite. Thus the regulations governing Lake Victoria's resources are different in each country which leads to governance weakness.

\section{Findings on Governance for Shared Waters}

The separation of environment, society and economy often leads to a narrow techno-scientific approach to management (Giddings et al., 2002) [42]. Leaders, however, must respond to not only the control of environmental pollution, but also proper anticipation of economic well-being, the objective of resource protection, respect of cultural heritage in the "people-plant-profit" regime.

In this context, we turn to the governance of Mekong River as an example. The governance of the Mekong River involves complex issues of multiple subjects and overlapping interests. Under the influence of water resources conflicts, climate change, and dam construction, the integration of nature, economy or society has proven difficult. Scientific methods and theoretical support of complex views are in need to strengthen the substantive promotion of consensus on cooperation within the river basin.

Hartig et al. (2018) [43] point out that adaptive planning and management in shared water resource management is an iterative learning process that integrates the environment with economic and social understanding and helps reduce uncertainty in management decisions. No governance model can satisfy all kinds of challenges. It may be appropriate for a strong command and control response to some challenges (perhaps climate change mitigation) and a decentralized collaborative decision-making response to local threats (such as flood mitigation).

Hirsch (2016) [44] notes that the field of critical geopolitics helps us recognize different societal perspective and also alerts us to the agendas behind them and their effect in generating particular types of developmental outcomes. Different stakeholders share the benefits of shared waters and believe they have equal rights to the development and protection of water resources. Geopolitics influences the opportunities for stakeholders to realize their desired outcomes, but predicting geopolitical trends is difficult. Nevertheless, waters shared by different political entities may be in different stages of social development which means that their capacity and goals of governance are dissimilar. Under such diverse conditions, it is unrealistic to expect that a "best" practice of water governance will encompass all countries and cities with very different physical, economic, social, political, cultural and institutional conditions (Biswas and Torta- 
jada, 2010) [45].

Adaptive governance is designed to address the inherent uncertainties in a system's response to management actions (Cosens and Williams, 2012) [46]. It seeks to use management intervention as a tool to probe the functioning of an ecosystem through identifying uncertainties and then establishing methodologies to test hypotheses concerning those uncertainties (Abdel-Fattah and Krantzberg, 2014) [47]. The types of uncertainties we refer to here include climate change, geopolitics and societal development.

\section{Regional Governance Scale}

The importance of spatial scale in the governing of natural resources in general and of water resources, in particular, is widely appreciated by geographers and international relations scholars (Table 1) (Feitelson and Fischhendler, 2009) [48]. Appropriate at the national scale are diplomatic negotiations, achieving cooperative agreements, and exchanging ideas on international issues. For example, water pollution in Lake Victoria demonstrates what happens when no one country is responsible for the entire lake (Kakonge, 1998) [49]. The lack of consultation and cooperation at the national level accounts for the weakness of Lake Victoria's governance system. Governance is socially, culturally, and politically embedded, and there is a tension between the generic principles of good governance applied through development programs and reform agendas, on one hand, and the specific relations of power, authority, collective decision making, and the determination of the common good in different country and local contexts, on the other (Hirsch, 2006) [44].

At a regional scale, it is necessary to have inter-organizational collaboration mechanisms, multilevel linkages for capital planning and polycentric policy initiatives. To achieve the purpose of collaboration, different regions need to nurture mutual trust and ensure information sharing as is the case in Chesapeake Bay.

The local scale requires active participation of the citizenry. As demonstrated in the case of Collingwood Harbour, it can build the public's sense of responsibility and resolve conflicts among stakeholders. Focusing on local scale assessment and multi-stakeholder participation enables communities to determine the

Table 1. Differences and relationships among three research scales.

\begin{tabular}{|c|c|c|}
\hline Scale & Status & Focus \\
\hline National & Macro & $\begin{array}{l}\text { International regulations and rules } \\
\text { Exchanging ideas on international issues } \\
\text { Diplomatic negotiations }\end{array}$ \\
\hline Regional & Integrating & $\begin{array}{l}\text { Interorganizational collaborative network } \\
\text { Multilevel capital planning } \\
\text { Polycentric policy initiatives }\end{array}$ \\
\hline Local & Micro & $\begin{array}{l}\text { Build the public's sense of responsibility } \\
\text { Resolve conflicts among stakeholders } \\
\text { Address social needs }\end{array}$ \\
\hline
\end{tabular}


appropriate actions based on available resources in combination with ongoing assessment, reporting and evaluation of the achievement of community goals (Norman et al., 2012) [50]. Through appropriate communication channels and inclusive methods, people with different skills, different ages, even life experiences can contribute to shared water governance and optimize decision-making.

Although governance frameworks will operate at different scales, they are interrelated, complementary, and partially overlapping. As Cohen and Davidson (2011) [51] commented: "unless all policy is made at a watershed scale (which is unrealistic, given international relations, transit within and between countries and regions, etc.), no single set of policies will ever wholly encompass the watershed".

Given the breadth of matters for resolution, we address good governance at the regional scale. Geographers define a region as a prescribed and specific unit (Chen, 2003) [52]. Different regions have unique administrative foundations and cultural systems. As Hirsch (2006) [39] notes, environmental reform in a region is driven by multiple agendas and is part of much wider social, economic, and political reform processes. The Mekong River again provides context for understanding water governance at a regional scale since there are multiple entities and intricate administrative boundaries. People with different cultural needs communicate and make governance decisions that can impact adjacent and interconnected areas.

\section{Conceptual Model for Adaptive Governance Process: A Regional Perspective}

Our conceptual model is designed to ensure equitable access to sufficient quantity and quality of water, as well as a range of ecosystem services for current and future generations (Wiek and Larson, 2012) [53]. A universal principle for the governance model for any region, as Hirsch (2006) [39] notes, should recognize the universality of water as a basic human right.

In the 1970s, the adaptive governance concept proposed by Holling was used to solve complex resource management problems beginning with Mori Forest ecosystem analysis. Steve et al. (2007) [54] highlighted that "adaptive governance refers to the evolution of rules and norms that better promote the satisfaction of underlying human needs and preferences given changes in understanding, objectives, and the social, economic and environmental context".

The governance model for shared water management needs to recognize the linkage among the natural, economic and social environments of the transboundary waters when making decisions. It is in this context we point to the Global Water Partnership (GWP) that was established in 1996 in response to international concern about deteriorating freshwater resources. Its Framework for Action stated that the water crisis is often a crisis of governance, and identified making water governance effective as one of the highest priorities for action (Rogers and Hall, 2003) [55].

Figure 1 is instructional regarding adaptation planning that is envisioned as a 


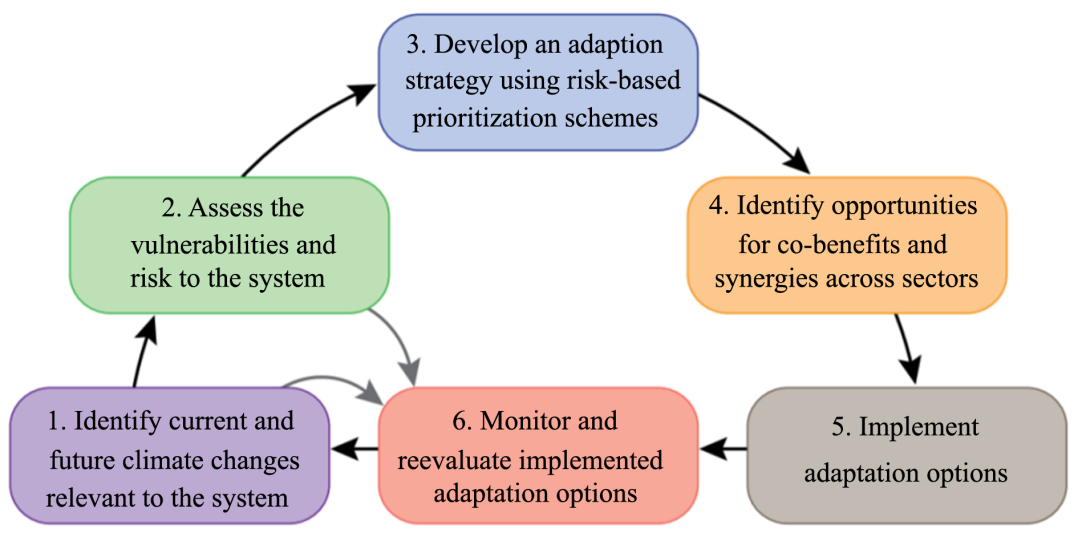

Figure 1. National research council adaptation framework.

cyclical, iterative process incorporating six steps (National Research Council, 2010). We need to accumulate experience, update insights and optimize governance strategies to adapt to the rapid changes in economic, natural and social conditions.

A similar model has been put forward by Allen et al. (2011) [56] who characterized adaptive management as "learning by doing". It is presented as two components, namely the structure of decision making and the need for learning and consists of 10 steps (Figure 2). Further, Ison and Wallis (2017) [57] defined adaptive governance steps as setting the "desired future condition", governance options, operationalization, evaluation and learning.

There are multiple governance options for adaptive governance goals There is a commonality in the existing adaptive governance models, that is, their basic form is a feedback loop, where an action is proposed, implemented, evaluated and decision making is intended to be adjusted or optimized in the next cycle.

Karpouzoglou et al. (2016) [8] stated that the governance model needs to become more progressive and radical than what adaptive governance theory suggests. We draw on existing models and methods to develop a more comprehensive governance model for shared waters (Figure 3). In general, we divided the governance process into four steps: setting of common goals, action interventions, monitoring and evaluation, and optimization.

It is well acknowledged that critical to success is the support of funds and accumulation of experience. However, sustained and adequate access to funds requires continuous socio-economic development and ideally, a decrease in remediation costs. Funding for protected areas will almost always be in short supply (Novellie et al., 2016) [58], thus it is particularly important to stimulate equity among business, legal representatives, government officials and other sectors affected by the quality of shared waters.

Our proposed generic model of adaptive governance includes feedback loops to evaluate uncertainties and propose solutions, and continually optimize through information feedback. The capacities to monitor relevant societal processes, to spot development opportunities and to take implementation measures are important (Janssen and Voort, 2016) [59]. One of the characteristics of 


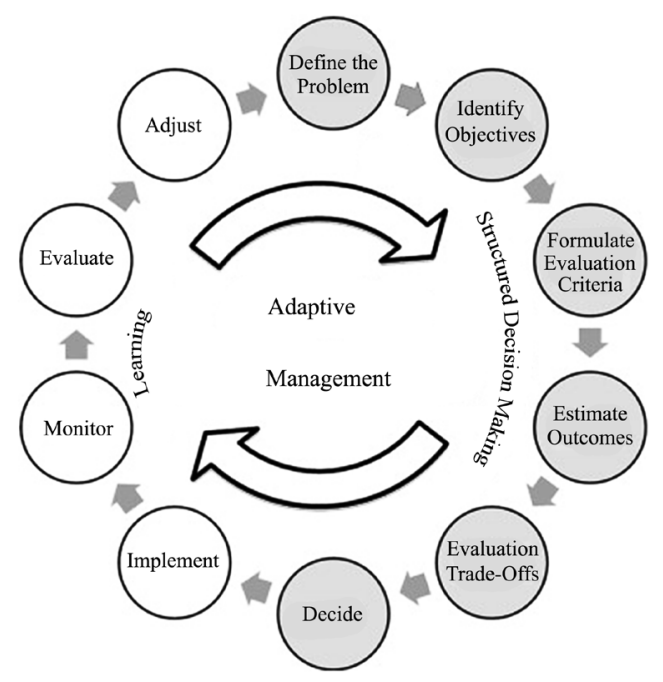

Figure 2. Adaptive management (Allen et al., 2011) [56].

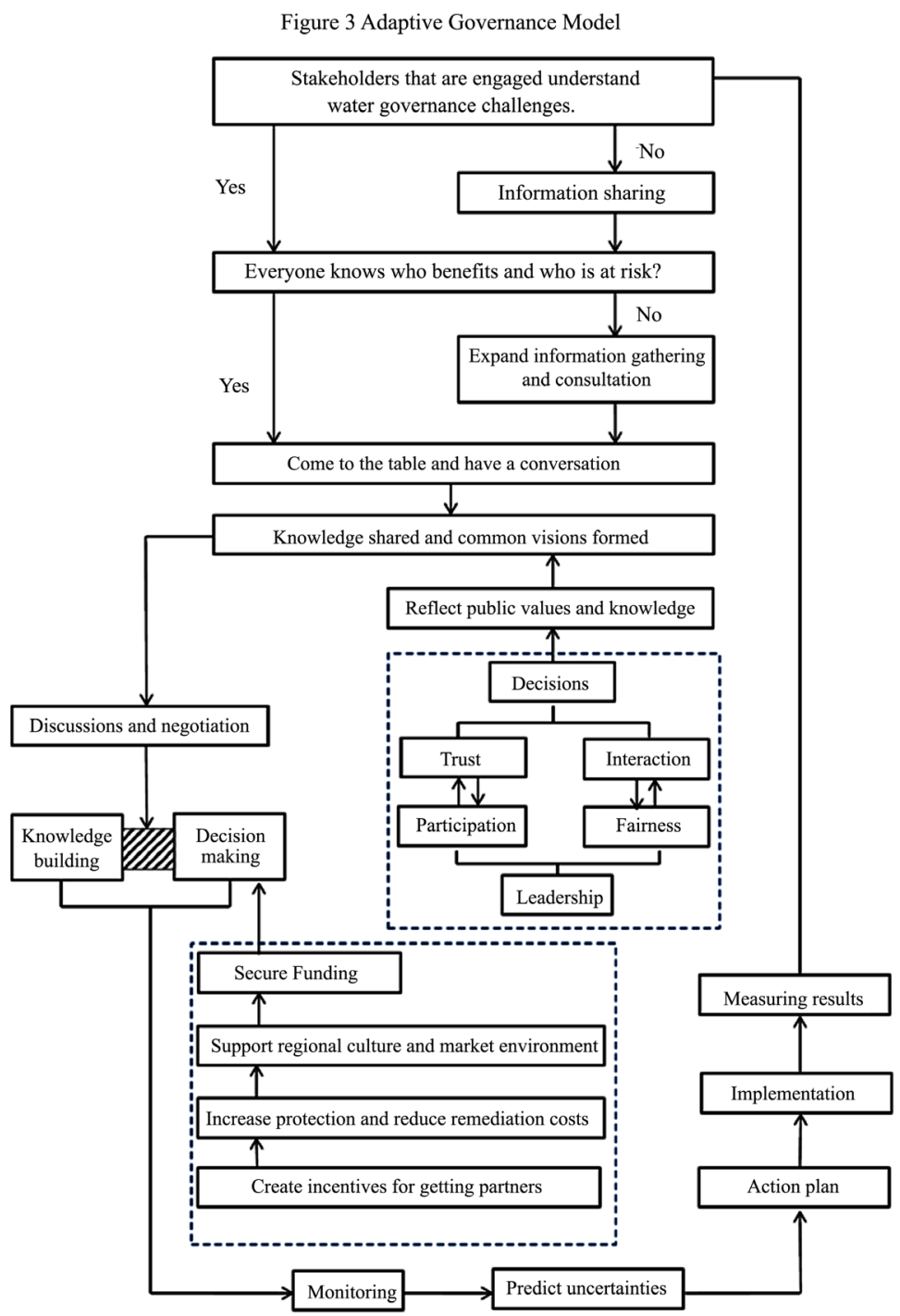

Figure 3. Shared water governance model with adaptive capacity. 
good governance is to continuously learn and incorporate different decision-making perspectives. Learning that helps develop adaptive expertise (an individual's ability to deal flexibly with new situations) and processes of sense-making are essential features in the governance of complex social-ecological systems, and these skills prepare managers for uncertainty and surprise (Folke et al., 2005) [12]. However, learning networks alone are not sufficient; some form of leadership must emerge to move the system to the next phase (Olsson et al., 2006) [60] in which the social compact can be formed, the learning cycle improved, and governance process adjusted.

\section{Effective Evaluation}

Effectiveness is defined in relation to delineating and achieving clear and sustainable water policy goals, laying out clear roles and responsibilities (Grafton et al. 2019) [61]. One important evaluation criteria for adaptive governance of shared waters is the learning capacity of the system participants. Armitage et al. (2007) [62] assert that by adopting the iterative learning of adaptive management, adaptive governance grew from the realization that challenges to co-management and adaptive management predominantly emerge from the arenas of governance. Folke et al. (2005) [12] also maintained that continuous learning is a critical component of adaptive governance.

Other metrics for evaluating good governance include measuring the degree of public participation and training, leadership, and knowledge sharing. These three aspects reflect the learning capacity for shared water governance: the learning atmosphere and learning content.

Expanding on our metrics, a measurement of accountable leadership helps determine the degree to which resources and equitable and rational decision-making is in place. Further, resilience, or the capacity of a system to absorb disturbance and reorganize while undergoing change would be measured by metric that determine how the function, structure, identity, and feedbacks are operating (Walker et al., 2004) [19]. Such attributes can be greatly enhanced through learning and innovation (Folke et al., 2005) [12].

Bish and McGinnis (1999) [63] note that polycentric government systems involve different types of governing authorities operating at various levels, by which many of the roles previously held by a central government are now carried out by non-state actors, including administration, regulation, management and mediation. Djalante et al. (2011) [20] argue that polycentric institutions influence the capacity to manage resilience, due to the existence of different organizations at different scales, which allows for a better matching of organizational and ecological scales (Folke et al., 2005) [12], an improved fit between knowledge and action (Lebel et al., 2006) [22], and the moderation of vertical interplay (Young and Gasser, 2002) [64].

The feasibility criteria to evaluate governance performance measure the extent to which decisions are made on a scientific and defensible basis. To evaluate this attribute, we consider the degree of accountability and capacity for funding. A 
high level of accountability can be determined through metrics that evaluate the fairness of regulations, quality of decisions and evidence of real improvements that can be assigned to the governance process.

Feasibility can also be determined by observations of tangible manifestations such as funding. Acess to funds addresses the ability to implement interventions like pollution control, infrastructure upgrades, and meaningful communication with the public and stakeholders. To maximize financing, there is also the opportunity to collaborate with new actors outside the water realm and to form more inclusive water development networks (Tropp, 2007) [65]. Table 2 presents descriptive indicators of governance effectiveness.

As Rauschmayer et al. (2009) [66] state, a timely evaluation enables corrective action on the governance process. Most experiments described in the governance literature are not so much interventions in ecosystems (such as the control of invasive species or the construction of dams) as they are policy experiments involving the application of different policy interventions (e.g., taxes, regulations) at various comparable locations so as to assess the determining features of their effectiveness (Huitema et al., 2009) [13].

We argue that criteria in terms of the capacity for learning, resilience and feasibility are required to evaluate the effectiveness of the governance process. Figure 4 illustrates the design of low and high levels of completion for each criterion and depicts the relationship between multiple performances to integrate security in natural, economic and social development in the water governance approach.

Table 2. Examples of metrics to measure the effects of shared water governance ${ }^{1}$.

\begin{tabular}{|c|c|c|}
\hline Target & Direction & Indicator \\
\hline & Nature & $\begin{array}{l}\text { Annual drought-affected area } \\
\text { Annual flood-affected area } \\
\text { Landscape diversity index } \\
\text { Biodiversity index } \\
\text { Number and width of ecological corridors }\end{array}$ \\
\hline $\begin{array}{l}\text { Adaptive governance } \\
\text { effects for shared waters }\end{array}$ & Society & $\begin{array}{l}\text { Pollution emissions per unit area } \\
\text { Per capita emissions of substance } \mathrm{x} \\
\text { Trends in irrigation rate of cultivated land } \\
\text { Water consumption per capita } \\
\text { Higher education enrollment rate } \\
\text { Public satisfaction with water co-managemen }\end{array}$ \\
\hline & Economy & $\begin{array}{l}\text { Investment in social capital } \\
\text { Investment natural capital } \\
\text { Remediation costs } \\
\text { Number of new jobs in water governance field } \\
\text { Annual income in sustainable fish harvest } \\
\text { Economic loss due to climate changes }\end{array}$ \\
\hline
\end{tabular}

${ }^{1}$ Scoring for these metrics are most appropriately calculated with as a collaborative, stakeholder engagement exercise. 


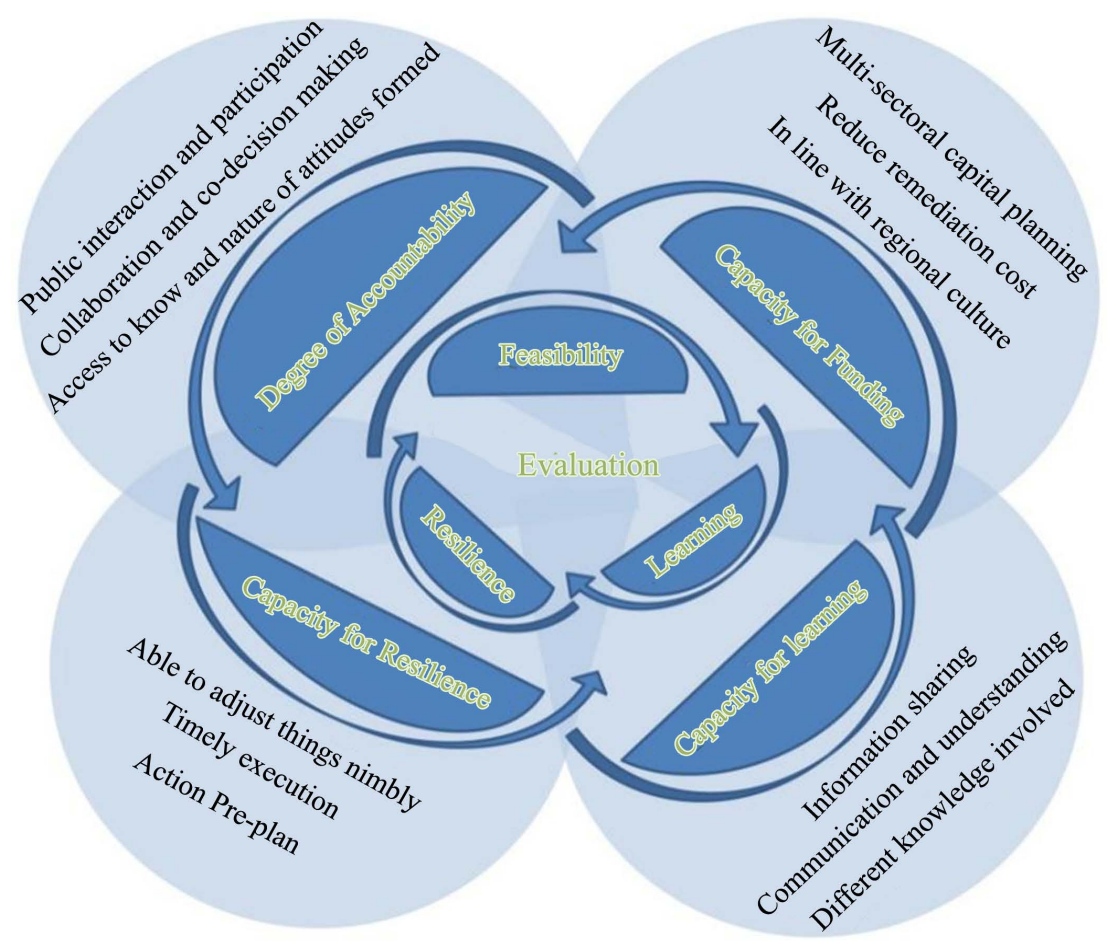

Figure 4. Effectiveness evaluation model.

\section{Conclusions}

When watershed boundaries overlap political and administrative boundaries, governance can be complicated. Cooperative efforts with diverse participants help to achieve the goal of protecting socio-ecology and economy systems. To address water resource management uncertainties (e.g. global climate, geopolitics and social development) and meet multiple needs (e.g. job creation, job creation and pollution cleanup), we have developed a conceptual model on adaptive governance for shared waters which is applicable at the regional scale.

To make the conceptual model flexible, comprehensive and effective, we divided adaptive governance into four steps: setting of common goals, action intervention, monitoring and evaluation, and optimization, which formed a feedback loop to enable the governance process to evolve capacities for learning and resilience. Similar to existing models, we have recommended a feedback loop where an action is proposed, implemented, evaluated and decision making is intended to be adjusted or optimized in the next cycle. Research on evaluating the effectiveness of the governance for shared waters enables the governance process to learn, enhances leadership, and ensures funding, accountability, and the capacity for resilience.

The case studies show why an adaptive governance model can benefit shared waters. These case studies (Collingwood Harbour, the Baltic Sea, Chesapeake Bay, Mekong River, and Lake Victoria) test abstract theories with applied experiences. Governance at the regional scale must address several challenges: accountability, diversity of participants and cooperation. These findings serve as a 
guide to emphasize inter-organizational collaboration mechanisms, multilevel linkage capital planning, and participants' engagement to optimize the governance process.

\section{Conflicts of Interest}

The authors declare no conflicts of interest regarding the publication of this paper.

\section{References}

[1] Nowlan, L. and Bakker, K. (2010) Practising Shared Water Governance in Canada: A Primer. UBC Program on Water Governance, Vancouver, Canada.

[2] Lautze, J., Silva, S.D., Giordano, M. and Sanford, L. (2011) Putting the Cart before the Horse: Water Governance and IWRM. Natural Resources Forum, 35, 1-8. https://doi.org/10.1111/j.1477-8947.2010.01339.x

[3] Ferreyra, C., Loë, R.C.D. and Kreutzwiser, R.D. (2008) Imagined Communities, Contested Watersheds: Challenges to Integrated Water Resources Management in Agricultural Areas. Journal of Rural Studies, 24, 304-321. https://doi.org/10.1016/j.jrurstud.2007.11.001

[4] Fish, R.D., Ioris, A.A. and Watson, N.M. (2010) Integrating Water and Agricultural Management: Collaborative Governance for a Complex Policy Problem. Science of the Total Environment, 408, 5623-5630. https://doi.org/10.1016/j.scitotenv.2009.10.010

[5] Giordano, M.A. and Wolf, A.T. (2003) Sharing Waters: Post-Rio International Water Management. Natural Resources Forum, 27, 163-171. https://doi.org/10.1111/1477-8947.00051

[6] Davis, C. (2014) Great Lakes Natural Resource Governance Symposium: The Good Governance Watershed. Indiana International \& Comparative Law Review, 24, 1-7. https://doi.org/10.18060/20955

[7] Dietz, T., Ostrom, E. and Stern, P.C. (2003) The Struggle to Govern the Commons. Urban Ecology, 302, 611-622. https://doi.org/10.18060/20955

[8] Karpouzoglou, T., Dewulf, A. and Clark, J. (2016) Advancing Adaptive Governance of Social-Ecological Systems through Theoretical Multiplicity. Environmental Science \& Policy, 57, 1-9. https://doi.org/10.1016/j.envsci.2015.11.011

[9] Akamani, K. and Wilson, P.I. (2011) Toward the Adaptive Governance of Transboundary Water Resources. Conservation Letters, 4, 409-416. https://doi.org/10.1111/j.1755-263X.2011.00188.x

[10] Brugnach, M., Dewulf, A., Pahl-Wostl, C. and Taillieu, T. (2008) Toward a Relational Concept of Uncertainty: About Knowing Too Little, Knowing Too Differently, and Accepting Not to Know. Ecology and Society, 13, 30. https://doi.org/10.5751/ES-02616-130230

[11] Hurlbert, M.A. and Diaz, H. (2013) Water Governance in Chile and Canada: A Comparison of Adaptive Characteristics. Ecology and Society, 18, 61. https://doi.org/10.5751/ES-06148-180461

[12] Folke, C., Hahn, T., Olsson, P. and Norberg, J. (2005) Adaptive Governance of Social-Ecological Systems. Annual Review of Environment and Resources, 30, 441-473. https://doi.org/10.1146/annurev.energy.30.050504.144511 
[13] Huitema, D., Mostert, E., Egas, W., Moellenkamp, S., Pahl-Wostl, C. and Yalcin, R. (2009) Adaptive Water Governance: Assessing the Institutional Prescriptions of Adaptive (Co-)Management from a Governance Perspective and Defining a Research Agenda. Ecology and Society, 14, 26. https://doi.org/10.5751/ES-02827-140126

[14] Munaretto, S., Siciliano, G. and Turvani, M. (2014) Integrating Adaptive Governance and Participatory Multicriteria Methods: A Framework for Climate Adaptation Governance. Ecology and Society, 19, 74. https://doi.org/10.5751/ES-06381-190274

[15] Pahl-Wostl, C. (2009) A Conceptual Framework for Analysing Adaptive Capacity and Multi-Level Learning Processes in Resource Governance Regimes. Global Environmental Change, 19, 354-365. https://doi.org/10.1016/j.gloenvcha.2009.06.001

[16] Weick, K.E. (1995) Sense Making in Organizations. Sage Publications, Thousand Oaks, CA.

[17] Berkes, F. (2008) Navigating Social-Ecological Systems: Building Resilience for Complexity and Change. Cambridge University Press, Cambridge.

[18] Holling, C.S. (1973) Resilience and Stability of Ecological Systems. Annual Review of Ecology and Systematics, 4, 1-23. https://doi.org/10.1146/annurev.es.04.110173.000245

[19] Walker, B., Holling, C.S., Carpenter, S.R. and Kinzig, A.P. (2004) Resilience, Adaptability and Transformability in Social-Ecological Systems. Ecology and Society, $\mathbf{9}$, 5. https://doi.org/10.5751/ES-00650-090205

[20] Djalante, R., Holley, C. and Thomalla, F. (2011) Adaptive Governance and Managing Resilience to Natural Hazards. International Journal of Disaster Risk Science, 2, 1-14. https://doi.org/10.1007/s13753-011-0015-6

[21] Lockwood, M., Davidson, J., Curtis, A., Stratford, E. and Griffith, R. (2010) Governance Principles for Natural Resource Management. Society \& Natural Resources, 23, 986-1001. https://doi.org/10.1080/08941920802178214

[22] Lebel, L., Anderies, J.M., Campbell, B., Folke, C., Hatfield-Dodds, S., Hughes, T.P. and Wilson, J. (2006) Governance and the Capacity to Manage Resilience in Regional Social-Ecological Systems. Ecology and Society, 11, 19. https://doi.org/10.5751/ES-01606-110119

[23] Ribot, J.C. (2002) African Decentralization: Local Actors, Powers and Accountability. UNRISD, Geneva.

[24] Badenoch, N. (2002) Transboundary Environmental Governance: Principles and Practice in Mainland Southeast Asia. World Resource Institute, USA.

[25] Salgado, P.P., Quintana, S.C., Pereira, A.G., del Moral Ituarte, L. and Mateos, B.P. (2009) Participative Multi-Criteria Analysis for the Evaluation of Water Governance Alternatives. A Case in the Costa del Sol (Málaga). Ecological Economics, 68, 990-1005.https://doi.org/10.1016/j.ecolecon.2006.11.008

[26] Krantzberg, G. and Houghton, E. (1996) The Remedial Action Plan That Led to the Cleanup and Delisting of Collingwood Harbour as an Area of Concern. Journal of Great Lakes Research, 22, 469-483. https://doi.org/10.1016/S0380-1330(96)70971-1

[27] Krantzberg, G. (2012) First off the List: The Collingwood Harbour Story. Great Lakes: Lessons in Participatory Governance. CRC Press, Taylor and Francis Group, Boca Raton, FL, 257-267. https://doi.org/10.1201/b13146-15

[28] Mostert, E. (2015) Who Should Do What in Environmental Management? Twelve 
Principles for Allocating Responsibilities. Environmental Science \& Policy, 45, 123-131. https://doi.org/10.1016/j.envsci.2014.10.008

[29] Beierle, T.C. and Konisky, D.M. (2001) What Are We Gaining from Stakeholder Involvement? Observations from Environmental Planning in the Great Lakes. Environment and Planning C: Government and Policy, 19, 515-527. https://doi.org/10.1068/c5s

[30] Krantzberg, G. (2006) Sustaining the Gains Made in Ecological Restoration: Case Study Collingwood Harbour, Ontario. Environment, Development and Sustainability, 8, 413-424. https://doi.org/10.1007/s10668-005-8504-7

[31] Krantzberg, G. and Farrer, N. (2019) The Collingwood Harbour Story. In: Hartig, J.H., Krantzberg, G., Austin, J.C. and McIntyre., P., Eds., Great Lakes Revival How Restoring Polluted Waters Leads to Rebirth of Great Lakes Communities, International Association of Great Lakes Research, Elsevier, 11-16.

[32] Hassler, B., Boström, M. and Grönholm, S. (2013) Towards an Ecosystem Approach to Management in Regional Marine Governance? The Baltic Sea Context. Journal of Environmental Policy \& Planning, 15, 225-245. https://doi.org/10.1080/1523908X.2013.766420

[33] Andersen, J., Korpinen, S., Laamanen, M., Wolpers, U., Claussen, U., Durkin, M., Hasselström, L., Ljungberg, R., Meski, L., Murray, C., Reker, J., Soutukorva, Å., Stankiewicz, M., Zweifel, U. and HELCOM (2010) Ecosystem Health of the Baltic Sea. HELCOM Initial Holistic Assessment 2003-2007. Baltic Sea Environmental Proceedings 122. Helsinki Commission, Helsinki, 63 p.

[34] Kapaciauskaite, I. (2011) Environmental Governance in the Baltic Sea Region and the Role of Non-Governmental Actors. Procedia-Social and Behavioral Sciences, 14, 90-100. https://doi.org/10.1016/j.sbspro.2011.03.027

[35] Arnstein, S.R. (2019) A Ladder of Citizen Participation. Journal of the American Planning Association, 85, 24-34. https://doi.org/10.1080/01944363.2018.1559388

[36] Jönsson, A.M. (2011) Framing Environmental Risks in the Baltic Sea: A News Media Analysis. Ambio, 40, 121-132. https://doi.org/10.1007/s13280-010-0124-2

[37] Boesch, D.F. (2006) Scientific Requirements for Ecosystem-Based Management in the Restoration of Chesapeake Bay and Coastal Louisiana. Ecological Engineering, 26, 6-26. https://doi.org/10.1016/j.ecoleng.2005.09.004

[38] Gerlak, A.K. and Heikkila, T. (2006) Comparing Collaborative Mechanisms in Large-Scale Ecosystem Governance. Natural Resources Journal, 46, 657-707.

[39] Hirsch, P. (2006) Water Governance Reform and Catchment Management in the Mekong Region. The Journal of Environment \& Development, 15, 184-201. https://doi.org/10.1177/1070496506288221

[40] Wang, H., Wang, T., Toure, B. and Li, F. (2012) Protect Lake Victoria through Green Economy, Public Participation and Good Governance. Environmental Science \& Technology, 46, 10483-10484. https://doi.org/10.1021/es303387v

[41] Nunan, F. (2010) Mobility and Fisher Folk Livelihoods on Lake Victoria: Implications for Vulnerability and Risk. Geoforum, 41, 776-785.

https://doi.org/10.1016/j.geoforum.2010.04.009

[42] Giddings, B., Hopwood, B. and Obrien, G. (2002) Environment, Economy and Society: Fitting Them Together into Sustainable Development. Sustainable Development, 10, 187-196. https://doi.org/10.1002/sd.199

[43] Hartig, J.H., Krantzberg, G., Munawar, M., Doss, M., Child, M., Kalinauskas, R. and Blair, C. (2018) Achievements and Lessons Learned from the 32-Year Old Cana- 
da-US Effort to Restore Impaired Beneficial Uses in Great Lakes Areas of Concern. Aquatic Ecosystem Health \& Management, 21, 506-520. https://doi.org/10.1080/14634988.2018.1539603

[44] Hirsch, P. (2016) The Shifting Regional Geopolitics of Mekong Dams. Political Geography, 51, 63-74. https://doi.org/10.1016/j.polgeo.2015.12.004

[45] Biswas, A.K. and Tortajada, C. (2010) Future Water Governance: Problems and Perspectives. International Journal of Water Resources Development, 26, 129-139. https://doi.org/10.1080/07900627.2010.488853

[46] Cosens, B.A. and Williams, M. (2012) Resilience and Water Governance: Adaptive Governance in the Columbia River Basin. SSRN Electronic Journal, 17, 3. https://doi.org/10.2139/ssrn.1942587

[47] Abdel-Fattah, S. and Krantzberg, G. (2014) Commentary: Climate Change Adaptive Management in the Great Lakes. Journal of Great Lakes Research, 40, 578-580. https://doi.org/10.1016/j.jglr.2014.05.007

[48] Feitelson, E. and Fischhendler, I. (2009) Spaces of Water Governance: The Case of Israel and Its Neighbors. Annals of the Association of American Geographers, 99, 728-745. https://doi.org/10.1080/00045600903066524

[49] Kakonge, J.O. (1998) EIA and Good Governance: Issues and Lessons from Africa. Environmental Impact Assessment Review, 18, 289-305. https://doi.org/10.1016/S0195-9255(98)00003-1

[50] Norman, E.S., Dunn, G., Bakker, K., Allen, D.M. and Albuquerque, R.C.D. (2012) Water Security Assessment: Integrating Governance and Freshwater Indicators. Water Resources Management, 27, 535-551. https://doi.org/10.1007/s11269-012-0200-4

[51] Cohen, A. and Davidson, S. (2011) The Watershed Approach: Challenges, Antecedents, and the Transition from Technical Tool to Governance Unit. Water Alternatives, 4, 1-14.

[52] Chen, R.L. (2003) Origin and Development of Regional Public Management Research. Political Studies, No. 4, 75-84. (In Chinese)

[53] Wiek, A. and Larson, K.L. (2012) Water, People, and Sustainability-A Systems Framework for Analyzing and Assessing Water Governance Regimes. Water Resources Management, 26, 3153-3171. https://doi.org/10.1007/s11269-012-0065-6

[54] Steve, H.D., Nelson, R. and Cook, D.C. (2007) Adaptive Governance: An Introduction and Implications for Public Policy (No. 10440). Australian Agricultural and Resource Economics Society.

[55] Rogers, P. and Hall, A.W. (2003) Effective Water Governance. Global Water Partnership, Stockholm.

[56] Allen, C.R., Fontaine, J.J., Pope, K.L. and Garmestani, A.S. (2011) Adaptive Management for a Turbulent Future. Journal of Environmental Management, 92, 1339-1345. https://doi.org/10.1016/j.jenvman.2010.11.019

[57] Ison, R.L. and Wallis, P.J. (2017) Position Statement on the Future of Great Lake Remedial Action Plans. Report of the Water Quality Board, Windsor, Ontario, Canada.

[58] Novellie, P., Biggs, H. and Roux, D. (2016) National Laws and Policies Can Enable or Confound Adaptive Governance: Examples from South African National Parks. Environmental Science \& Policy, 66, 40-46.

https://doi.org/10.1016/j.envsci.2016.08.005 
[59] Janssen, M. and Van Der Voort, H. (2016) Adaptive Governance: Towards a Stable, Accountable and Responsive Government. Government Information Quarterly, 33, $1-5$.

[60] Olsson, P., Gunderson, L.H., Carpenter, S.R., Ryan, P., Lebel, L., Folke, C. and Holling, C.S. (2006) Shooting the Rapids: Navigating Transitions to Adaptive Governance of Social-Ecological Systems. Ecology and Society, 11, 18.

https://doi.org/10.5751/ES-01595-110118

[61] Grafton, R.Q., Garrick, D., Manero, A. and Do, T.N. (2019) The Water Governance Reform Framework: Overview and Applications to Australia, Mexico, Tanzania, USA and Vietnam. Water, 11, 137. https://doi.org/10.3390/w11010137

[62] Armitage, D., Berkes, F. and Doubleday, N. (2007) Adaptive Co-Management: Collaboration, Learning and Multi-Level Governance. UBC Press.

[63] Bish, R.L. and Mcginnis, M.D. (1999) Polycentric Governance and Development: Readings from the Workshop in Political Theory and Policy Analysis. The University of Michigan Press, Ann Arbor, MI, 118.

[64] Young, O.R. and Gasser, L. (2002) The Institutional Dimensions of Environmental Change: Fit, Interplay, and Scale. MIT Press.

[65] Tropp, H. (2007) Water Governance: Trends and Needs for New Capacity Development. Water Policy, 9, 19-30.

https://doi.org/10.2166/wp.2007.137

[66] Rauschmayer, F., Berghöfer, A., Omann, I. and Zikos, D. (2009) Examining Processes or/and Outcomes? Evaluation Concepts in European Governance of Natural Resources. Environmental Policy and Governance, 19, 159-173.

https://doi.org/10.1002/eet.506 